\title{
Relationship between Students' Attitudes in Space Science with Their Achievements in the Field
}

\author{
Rosadah Abd Majid1, Mardina Abdullah"2,3, Badariah Bais ${ }^{2}$, Nor Syaidah Bahri', \\ Mohd Hezri Mokhtar ${ }^{4}$, Siti Aminah Bahari ${ }^{3}$ \\ ${ }^{1}$ Department of Education and Community Wellbeing, Faculty of Education, Universiti Kebangsaan Malaysia, \\ Bangi, Malaysia \\ ${ }^{2}$ Department of Electrical, Electronic and Systems Engineering, Faculty of Engineering and Built Environment, Universiti \\ Kebangsaan Malaysia, Bangi, Malaysia \\ ${ }^{3}$ Space Science Centre (ANGKASA), Institute of Climate Change, Universiti Kebangsaan Malaysia, Bangi, Malaysia \\ ${ }^{4}$ Faculty of Engineering Technology, Universiti Tun Hussein Onn Malaysia, Parit Raja, Malaysia \\ Email:rosadah@ukm.edu.my
}

How to cite this paper: Majid, R. A., Abdullah, M., Bais, B., Bahri, N. S., Mokhtar, M. H., \& Bahari, S. A. (2018). Relationship between Students' Attitudes in Space Science with Their Achievements in the Field. Creative Education, 9, 2291-2299.

https://doi.org/10.4236/ce.2018.914169

Received: August 16, 2018

Accepted: October 27, 2018

Published: October 30, 2018

Copyright (C) 2018 by authors and Scientific Research Publishing Inc. This work is licensed under the Creative Commons Attribution International License (CC BY 4.0).

http://creativecommons.org/licenses/by/4.0/

\begin{abstract}
The purpose of this study is to identify the relationship between students' attitude in space science with their achievement in the field. This study also examines students' performance in space science. A total of 458 of secondary school students participated in this study. The questionnaire for this study was divided into two parts. The first part contains 9 items about students' attitudes towards space science while the second part consists of 20 questions of general knowledge about space science. The findings show that students' general knowledge about space science is at moderate level. The result also shows a significant relationship between students attitude with their achievement towards space science.
\end{abstract}

Keywords

Space Science, Attitude, Achievement, Relationship

\section{Introduction}

Science is a field of knowledge which is a result of empirical studies to explain the creation of the universe. In Malaysia, science is one of the required subjects for students in primary and secondary schools. Space science is one of the sub topics in science syllabus. Space science is associated with mathematics, physics, astronomy, chemistry, geology and biology (Jordan, 2002). Space science pro- 
grams in developed countries have been initiated with so much effort by their scientists to go to orbit of the earth and to earth's space (Lee, Jo, \& Choi, 2011). In early 90's, space science activities in Malaysia was mainly done at the universities such as University DarulIman Malaysia for astrophotography, University Science Malaysia for atmospheric physics and Moon crescent studies, University of Malaya for CCD studies of sky objects and the National University of Malaysia (UKM-Universiti Kebangsaan Malaysia) for UV astronomy studies. The establishment of the National Planetarium Kuala Lumpur in 1994 which also houses a small observatory has encouraged further space science activities through the study on sky extinction co-efision and astrophotography. Amateur astronomers during those years were mainly doing astrophotography. After more than a decade, Malaysia will now move further in space science studies under four main fields including Astronomy, Micro Gravity Sciences, Space Weather Research and Scientific Payload Onboard Spacecraft (National Space Agency, 2013).

Space offers any country in the world to do exploration. Thus, Malaysia cannot just sit back and see other countries develop their own space technologies as abilities in space technology is particularly important in terms of defence, security, surveys and data collection for the study of weather (Saiful, 2009). In an effort to develop space science, it is still not too late for Malaysia to spur the development of this technology compared to other developing countries such as India, China and Brazil. With the establishment of several space-related institutions, it is proven that Malaysia is determined to develop space fields as in line with other developed countries such as Russia, USA and Japan.

School programs should nature knowledge and understanding as well as high positive attitude and passion for space science. Students' knowledge of space science fields can be obtained from various sources and media. Students' interest towards space science should be fostered while they were in school because the field of space exploration is a never-ending project. Malaysia is not exempted from this exploration as the nation aspires to be a developed nation by 2020. In February 2017, the National Space Policy which is fundamental to the formulation of the space act, has been approved. Moreover, capacity building should be enhanced in order to support this national agenda. Despite that, space science still requires the utilization of high-end technologies that will end up in consumer products. The technology eventually will bring large returns in the long term and thus, boosts the national income to a higher level.

\section{Attitudes and Achievement}

Students are important assets in expanding knowledge on space science. Students should have awareness of space science because they are agents of information dissemination to the community at large. To understandstudents' attitudes is important in supporting their achievement and interest towards a particular discipline (Pavol, Gaye, \& Julia, 2007). There are various definitions that 
have been used by several researchers to define attitude. Attitudes are one of the major determiners of human behaviour. Attitudes of individuals strongly affect their love, hatred and behaviours (Morgan, 1991). Attitude is a phenomenon that is attained through learning, which guides the behaviours of an individual and causes subjectivity. Having positive attitudes towards a school subject would involve behaviours such as willingness to participate in a lesson, satisfaction by responding to questions, accepting one's own value and agreeing one value to be recognized (Ozcelik, 1998).

According to Kind, Jones \& Barmby (2007), attitude is the feeling that a person has about an object, based on his or her knowledge and belief about that object. This definition is based on the model that attitude composed of three components of cognition, affect and behavior. Attitudes are a personal factor and they are referring to one's positive or negative judgment about a concrete subject. Attitudes are determined by the analysis of the information regarding the result of an action and by the positive or negative evaluation of these results (Ajzen \& Fishbein, 1977). Attitude towards science is a combination of sense, belief and values towards an object that is a product of science, science class or an effect on science, public and scientists (Osborne, 2003).

According to Erduran (2007), attitude toward science is an important component of argumentation skill. There are no measures of teachers' and students' attitudes and beliefs about the role of argument in science education. Schwirian (1967) stated that attitude towards science is the basis of acceptance and support of science or the basis of rejection of science and scientific activities in a society. Therefore, the decline in attitude of acceptance towards science may result in the decrease of scientific research support, for today's students will be tomorrow scientists and decision maker in the society.

Previous studies show that Malaysian students' have positive attitude towards sciences (Paniandi, 2009). Unfortunately, positive attitude is not enough to attract students for choosing science. According to Fatin, Mohd and Mohammad (2012), there are several factors contributing to the declining number of students choosing in science in Malaysia. The main contributing factors were found to be originated from the difficulties in learning and getting good grades in science related subjects or courses. Other factors include influence of peers and parents who may not be supportive of science, the perception of less opportunity for science majors to pursue tertiary level education, lack of knowledge and exposure to careers for science graduates, and limited coaching on the importance of science field to secondary school students.

Achievement on the other hand is a measurement of individual's proficiency in specific field (Mohd Majid, 1998). In addition, achievement generally means a success or a failure of students in a test, school examination or standard examinations which are designed, administered, scored and interpreted by experts in the particularly field or subject. Usually achievements are expressed in raw scores, grades and rank for a given subject or the entire course. In general, 
achievement is determined from an individual's level of attainment in a pre-established system of assessment (Othman \& Rahmadhaniah, 2010). Students who expressed high levels of self-confidence of learning science have been found to obtain higher academic achievements in science related subjects (Ebrahim, Ahmadreza, \& Shojae, 2015). On the contrary, students who are lack of confidence in their ability to learn what they judge to be important and to overcome difficulties may not find success, not only in school but also in their adult lives. For instance, House and Telese (2017) examined the relationship between confidence in science and achievement test scores for a national sample of fourthgrade students from Korea who participated in the TIMSS (Trends in International Mathematics and Science Study) 2011 assessment. They found that students who showed high achievement levels in science were more likely to report that they learned things quickly in science and did well in science; yet students who expressed negative comparisons of themselves to others tend to have lower science achievement.

Attitude and achievement should be positively related, so that higher achievement would lead to more positive attitudes and vice versa (Papanastasiou \& Zamblylas, 2002). Indeed several studies found that science attitudes were positively correlated with science achievement and participation in advance science courses (Simpson \& Oliver, 1990). Achievement could be attributed to students' attitudes towards the subject, as well as towards their school environment and their self-belief. Many studies have been conducted in schools regarding relationship between students' attitudes with achievement (Ercan et al., 2009). Review of literature showed that student's attitude plays an important role in determining their achievement. Even at different ability levels, the increase in achievement was attributed to increments in attitude scores.

Papanastasiou (2000) in his research found a positive relationship between mathematics achievement and students' attitudes towards mathematics. Direct effect of attitude on performance has also been shown by Pajares \& Miller (1994) and a positive significant correlation between students' attitude and academic achievement has been observed in the works Zimmerman, Bandura and Martinez-Pons (1992). They also reported a path analysis for final grades of $9^{\text {th }}$ and $10^{\text {th }}$ graders and the students' attitudes. Kamariah et al. (2010) also found that students' academic achievement was correlated significantly with their attitudes towards learning in Malaysia higher educational institutions. In addition, some researchers also propose that the weak association between attitudes and achievement might also be related to the perceived difficulty of science, the lack of effective teaching and the influence of ethnic and home background. Therefore, this present study is to examine students' attitudes towards space science and relationship with their achievement in space science related knowledge.

\section{Purpose of This Study}

The purpose of this study is to look at the achievement of students in general 
knowledge of space science and its relationship with their attitudes towards space science. Questions to be studied are:

- What is the level of achievement of students in general knowledge about space science?

- What is the mean score for students' attitudes and achievement in space science?

- Is there any correlation between students' attitudes with achievement in space science?

\section{Methodology}

The study was conducted through a descriptive survey method and samples were selected based on stratified random sampling. Specifically, the surveys were conducted using a "cross-sectional" method (Gall, Gall, \& Borg, 2003) in which the data were obtained at the same time but from different group of students. There were 458 of 16 years old students in science stream classes involved in this study. This study is limited to 6 selected secondary schools in Selangor, Malaysia only. The questionnaire for this study consisted of two parts. Part A consists of 9 items about students attitudes towards space science. Response of each item is based on the Likert scale of five points ranging from "strongly agree", "agree", "not sure", "disagree" and "strongly disagree" with point given as 5, 4, 3, 2, and 1 respectively. Part B consists of 20 multiple questions on general knowledge of students about space science. All items and questions in this part are written in both Malay and English language in order to facilitate the students in answering the questions. This is to ensure language is not a barrier factor for students to understand the meaning of questions. Data was analysed using descriptive and inferential statistic to answer the research questions which include the use of frequency, percentage, mean and correlation.

\section{Results and Discussions}

As illustrated in Table 1, majority of students $(\mathrm{n}=252,55 \%)$ scored at the range of $41-60$ percent in the test that measure their general knowledge about space science. A total of 107 (23.4\%) students managed to get the score between 61 to 80 percent. Only 8 (1.7\%) students scored between 81 to 100 percent. For the low score which is between 21 to 40 percent, a total of 87 (19\%) people get that score and only $4(0.9 \%)$ people score between 0 to 20 percent. This indicates that students' general knowledge in space science is still at a moderate level. Data also showed that there were students who are still less sensitive to current issues regarding space science. The result also is affected by the survey questions which some can be considered too in-depth about space science, yet space science is not a major subject in science syllabus. However, exposure of space science is important for students to develop their interest in this field.

Table 2 showed that mean score and standard deviation of students' achievement in general knowledge about space science was 10.65 out of 20.00 with 
Table 1. School student achievement in test on space science.

\begin{tabular}{ccc}
\hline Score Categories (\%) & Frequency & Percentage (\%) \\
\hline $0-20$ & 4 & 0.9 \\
$21-40$ & 87 & 19.0 \\
$41-60$ & 252 & 55.0 \\
$61-80$ & 107 & 23.4 \\
$81-100$ & 8 & 1.7 \\
Total & 458 & 100 \\
\hline
\end{tabular}

Table 2. Descriptive statistic for students' achievement and attitudes towards space science.

\begin{tabular}{ccc}
\hline Variables & Mean & St. Dev \\
\hline Students' achievement & 10.65 & 2.64 \\
Students' attitudes & 3.85 & 0.60 \\
\hline
\end{tabular}

standard deviation of 2.64. The mean score for students' attitudes towards space science was 3.85 out of 5.00 with a standard deviation of 0.60 . The average point between 3.00 and 4.00 was considered within the category of "I agree", therefore it is plausible to conclude that students have expressed positive attitudes towards space science.

Results of correlation analysis in Table 3 showed that the relationship between students attitudes with achievement of space science was $\mathrm{r}=0.21, \mathrm{p}=0.00(\mathrm{p}<$ 0.05 ). Correlation coefficient value obtained showed that there was significant positive relationship. It means students with positive attitudes towards space science will be more likely to obtain higher score in achievement test. If students have a positive attitudes towards a subject, usually they will show positive behaviour towards the subject such as showing interest in the knowledge taught by the teacher, giving positive response during the teaching and learning process such as always asking question, not sleepy and actively participating in all the activities carried out either in the classroom or in the laboratory. Consequently, students who have positive attitude will usually obtain good score in achievement test. Similarly, if students have a negative attitude towards a particular subject, they will show negative behaviour on the subject such as not showing interest on the science subject taught by the teacher, not showing good response during lessons such as not asking questions, sleepy, did not participate in lab activities and group work and obtain bad result. Therefore, instilling a positive attitude is important in order to promote effective learning process (Kamisah, Zanato, \& Lilia, 2007) (Table 3).

\section{Conclusion}

Overall the study found that students' achievement in general knowledge about space science is at an average level of 41 to 60 percent. The questions about space 
Table 3. Correlation between students' attitude with their achievement of space science.

\begin{tabular}{ccccc}
\hline Variables & $\mathrm{N}$ & $\mathrm{r}$ & $P$-value & Sig \\
\hline $\begin{array}{c}\text { Students' attitude and } \\
\text { achievement }\end{array}$ & 458 & 0.21 & 0.00 & $\mathrm{~S}$ \\
\hline
\end{tabular}

Correlation is significant at the 0.01 level (2-tailed).

science were more focused on general knowledge that can be read from mass media such as the Internet, newspapers, science magazines and so on. Therefore, this performance was not affected by types of school. In fact, students from daily schools are able to get good results if they are sensitive towards issues of space science. In addition, students' attitudes have shown to have great influence on their achievement of space science. Positive students' attitudes towards space science encouraged students to get to know basic and common things in this area. Positive attitude and achievement in this field will allow students to continue to learn and take advanced courses at higher level post high school graduation. Positive attitude and good response and support from all parties including schools, teachers and parents will improve students' achievement on space science in ensuring continuity of this field to move forward in the future.

\section{Acknowledgements}

The project was funded by UKM's internal grant (Komuniti 2012-016) and the Ministry of Science, Technology and Innovation (MOSTI) grant (KK2013-008).

\section{Conflicts of Interest}

The authors declare no conflicts of interest regarding the publication of this paper.

\section{References}

Ajzen, I., \& Fishbein, M. (1977). Attitude-Behavior Relations: A Theoretical Analysis and Review of Empirical Research. Psychological Bulletin, 84, 888-918. https://doi.org/10.1037/0033-2909.84.5.888

Ebrahim, M., Ahmadreza, S., \& Shojae, A. K. (2015). Multilevel Modeling of Science Achievement in the TIMSS Participating Countries. The Journal of Educational Research, 108, 449-464.

Ercan, A., Eylem, Y., Nilgün, T., \& Ömer, E. (2009). Students' Attitudes toward Science and Technology: An Investigation of Gender, Grade Level, and Academic Achievement. Procedia Social and Behavioral Sciences, 1, 2804-2808. https://doi.org/10.1016/j.sbspro.2009.01.498

Erduran, S. (2007). Argumentation in Science Education: Perspectives from ClassroomBased Research. Springer. https://doi.org/10.1007/978-1-4020-6670-2

Fatin, A. P., Mohd, S. A., \& Mohammad, B. A. (2012). Faktor penyumbang kepada kemerosotan penyertaan pelajar dalam aliran sains: Satu analisis sorotan tesis. Sains Humanika, 2, 63-71.

https://sainshumanika.utm.my/index.php/sainshumanika/article/view/469/425

Gall, M., Gall, J. P., \& Borg, W. R. (2003). Educational Research: An Introduction. 
Boston: Longman.

House, J. D., \&Telese, J. A. (2017). Confidence in Science and Achievement Outcomes of Fourth-Grade Students in Korea: Results from the TIMSS 2011 Assessment. Education, 137, 389-392.

Jordan, D. M. (2002). Mental Discipline, Curricular Reform, and the Decline of U.S. Astronomy Education, 1893-1920. The Astronomy Education Review, 1, 58-75.

Kamariah, A. B., Rohani, A. T., Rahil, M., Habibah, E., Wong, S. L., \& Ahmad, F. M. A. (2010). Relationships between University Students' Achievement Motivation, Attitude and Academic Performance in Malaysia. Procedia Social and Behavioral Sciences, 2, 4906-4910. https://doi.org/10.1016/j.sbspro.2010.03.793

Kamisah, O., Zanaton, H. I., \& Lilia, H. (2007). Sikap terhadap sains dan sikap saintifik di kalangan pelajar sains. Jurnal Pendidikan, 32, 39-60.

Kind, P. M., Jones, K., \& Barmby, P. (2007). Developing Attitudes towards Science Measures. International Journal of Science Education, 871-893. https://doi.org/10.1080/09500690600909091

Lee, J., Jo, H. J., \& Choi, J. D. (2011). The Organizations for Space Education and Outreach Programs in the Republic of Korea. Acta Astronautica, 69, 730-736. https://doi.org/10.1016/j.actaastro.2011.05.004

Mohd Majid, K. (1998). Kaedah Penyelidikan Pendidikan. Kuala Lumpur: Dewan Bahasa dan Pustaka.

Morgan, C. T. (1991). Introduction to Psychology. ( $8^{\text {th }}$ ed.). Ankara: Hacettepe University Department of Psychology Publications.

National Space Agency (2013). http://www.angkasa.gov.my/?q=en/node/59

Osborne, J. (2003). Attitudes towards Science. A Review of the Literature and Its Implications. International of Science Education, 25, 1049-1079. https://doi.org/10.1080/0950069032000032199

Othman, M. J., \& Rahmadhaniah, A. M. (2010). Faktor-faktor yang mempengaruhi pencapaian akademik pelajar tahun 4 Perdana, Jabatan Pendidikan Teknikal dan Kejuruteraan, Sesi 2007/2008, Fakulti Pendidikan UTM, Skudai. http://eprints.utm.my/id/eprint/11050/1/Faktor.pdf

Ozcelik, D. A. (1998). Measurement and Evaluation. Ankara: OSYM Publications.

Pajares, F., \& Miller, M. D. (1994). Role of Self-Efficacy and Self-Concept Beliefs in Mathematical Problem Solving: A Path Analysis. Journal of Educational Psychology, 86, 193-203. https://doi.org/10.1037/0022-0663.86.2.193

Paniandi, G. (2009). Persepsi pelajar terhadap saintis dan kefahaman pelajar dalam sains (sekolah menengah). Master Thesis. Universiti Putra Malaysia.

Papanastasiou, C. (2000). Effects of Attitudes and Beliefs on Mathematics Achievement. Studies in Educational Evaluation, 26, 27-42.

https://doi.org/10.1016/S0191-491X(00)00004-3

Papanastasiou, C., \& Zembylas, M. (2002). The Effect of Atttitudes on Science Achievement: A Study Conducted among High School Pupils in Cyprus. International Review of Education, 48, 468-484. https://doi.org/10.1023/A:1021334424571

Pavol, P., Gaye, T., \& Julia, C. (2007). Slovakian Students Attitudes towards Biology. Eurasian Journal of Mathematics, Science \& Technology Education, 3, 287-295.

Saiful, B. A. (2009). Kerjasama Serantau Dalam Dunia Angkasa. Selangor: Penerbitan Premier.

Simpson, R. D., \& Oliver, J. S. (1990). A Summary of Major Influences on Attitude 
toward and Achievement in Science among Adolescent Students. Science Education, 74, 1-18. https://doi.org/10.1002/sce.3730740102

Zimmerman, B. J., Bandura, A., \& Martinez-Pons, M. (1992). Self-Motivation for Academic Attainment: The Role of Self-Efficacy Beliefs and Personal Goal Setting. American Educational Research Journal, 29, 663-676. https://doi.org/10.3102/00028312029003663 